\title{
Coral Ecosystem Resilience, Conservation and Management on the Reefs of Jamaica in the Face of Anthropogenic Activities and Climate Change
}

\author{
M. James C. Crabbe \\ LIRANS Institute for Research in the Applied Natural Sciences, Faculty of Creative Arts, \\ Technologies and Science, University of Bedfordshire, Park Square, Luton, LU1 3JU, UK; \\ E-Mail: james.crabbe@beds.ac.uk; Tel.: +44-1582-489-265; Fax: +44-1582-489-212
}

Received: 13 March 2010; in revised form: 26 April 2010 / Accepted: 18 May 2010 /

Published: 1 June 2010

\begin{abstract}
Knowledge of factors that are important in reef resilience and integrity help us understand how reef ecosystems react following major anthropogenic and environmental disturbances. The North Jamaican fringing reefs have shown some recent resilience to acute disturbances from hurricanes and bleaching, in addition to the recurring chronic stressors of over-fishing and land development. Factors that can improve coral reef resilience are reviewed, and reef rugosity is shown to correlate with coral cover and growth, particularly for branching Acropora species. The biodiversity index for the Jamaican reefs was lowered after the 2005 mass bleaching event, as were the numbers of coral colonies, but both had recovered by 2009 . The importance of coastal zone reef management strategies and the economic value of reefs are discussed, and a protocol is suggested for future management of Jamaican reefs.
\end{abstract}

Keywords: tropical storms; hurricanes; economics; bleaching; rugosity; Caribbean; global warming; coral growth; recruitment; ICZM; MPA; biodiversity; Discovery Bay 


\section{Introduction}

Coral reefs throughout the world are under severe challenges from a variety of anthropogenic and environmental factors including overfishing, destructive fishing practices, coral bleaching, ocean acidification, sea-level rise, algal blooms, agricultural run-off, coastal and resort development, marine pollution, increasing coral diseases, invasive species, and hurricane/cyclone damage [1,2]. Most reefs are considered as open non-equilibium systems [3], with diversity maintained by disturbance and recruitment, as well as by predation, competition and evolutionary history [4]. Interspecific competition [5,6] is pervasive among coral communities, and is important in maintaining their viability [7,8]. Heterospecific competition of corals with algae reduces coral growth and survivorship [9,10]. In corals, spatial arrangement, orientation and aggregation may be a key mechanism contributing to species coexistence on coral reefs [11,12]. Maintaining coral reef populations in the face of large scale degradation and phase-shifts on reefs depends critically on recruitment [13,14], maintenance of grazing fish and urchin populations [15], clade of symbiotic zooxanthellae [16] and management of human activities related to agricultural land use and coastal development [17]. To manage coral reefs it is important to have an understanding of coral population demography-structure, biodiversity and and dynamics [18-20]. Ideally, this involves the quantification of numbers of individual colonies of different size classes - the population structurethrough time, in addition to quantifying coral growth rates, recruitment and survival.

The fringing reefs around Discovery Bay in Jamaica (Figure 1) constitute one of the best documented areas of reef decline in the Caribbean, where loss of corals and macroalgal domination has been due to hurricanes [21,22], overfishing [23,24], die-off of the long-spined sea urchin Diadema antillarum in 1983-1984 [25], and coral disease [26]. Nutrient enrichment does not appear to have been a causal factor in the development of the reef macroalgal communities [27]. Interestingly, increased macroalgal cover by itself does not always lead to reef decline, and the Jamaican example may be an anomaly compared to reefs in other parts of the world [28,29]. The fringing reefs around Discovery Bay have seen a number of challenges in recent years, notably several hurricanes as well as a mass bleaching event in the Caribbean in 2005 [30-33]. Despite all these negative factors, there is evidence that prior to 2005 some Discovery Bay reefs were recovering [34]. Indeed, quantification of numbers of individual colonies of different size classes through time, in addition to quantifying coral growth rates, recruitment and survival, bore this out both before and after the mass bleaching event [33]. Healthy reefs have a high proportion of small size-classes that include new recruits and juveniles [35], and the smallest size class of corals can be a good indicator of reef resilience $[3,36]$.

The Caribbean-wide bleaching event of 2005 was due primarily to high sea surface temperature (SST) hot-spots in the region [37-39]. Thermal stress during this event exceeded any seen in the previous 20 years of satellite data from the Caribbean, while monthly temperatures were the warmest in over 150 years. The North Jamaican fringing reefs, unlike elsewhere in Caribbean, for example the reefs of Tobago [40], have shown resilience to acute disturbances from hurricanes and bleaching, in addition to the recurring chronic stressors of overfishing and land development [33,34]. Factors that can improve coral reef resilience include species and functional diversity, connectivity to larval sources, appropriate substrates for larval settlement, and protection from other anthropogenic effects $[41,42]$. 
Figure 1. Satellite image showing the location of fringing reef sites (Rio Bueno, M1, New Reef, Dancing Ladies, Dairy Bull and Pear Tree Bottom) around Discovery Bay, Jamaica. DBML, Discovery Bay Marine Laboratory. The horizontal line shows $1 \mathrm{~km}$ distance.

\section{Rio Bueno}

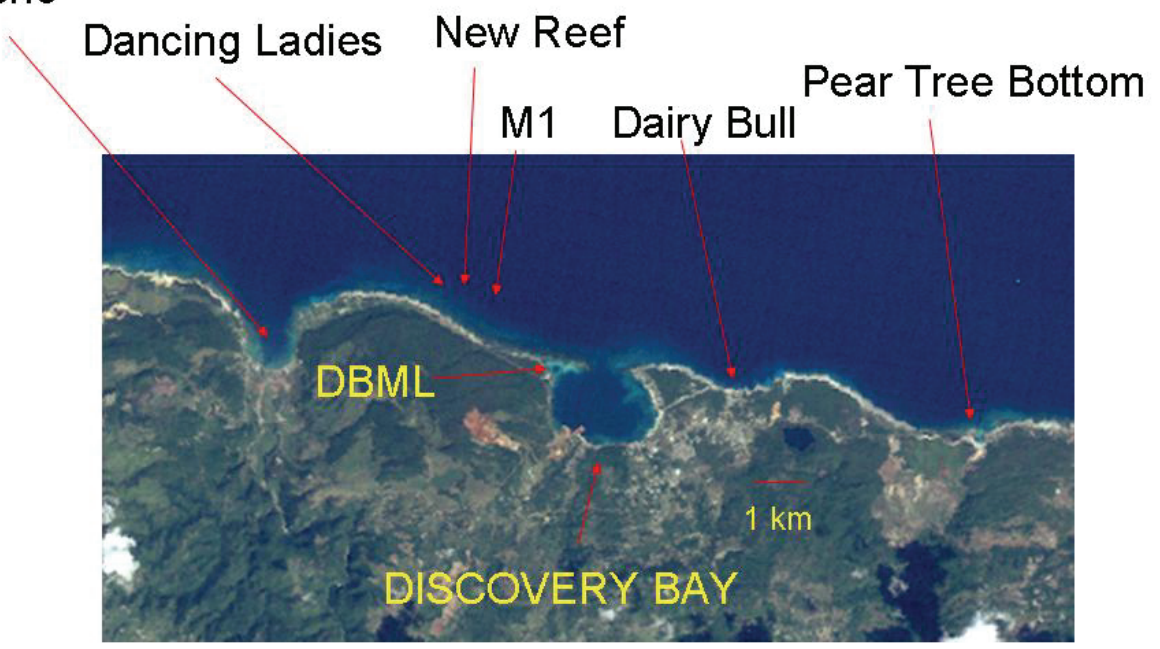

Decline in architectural complexity of Caribbean reefs has been apparent since the 1980s, and coincide with key events in recent Caribbean ecological history [43]. Rugosity - three dimensional topography and complexity — has been linked to reef resilience in the South Central Pacific [44] and has been selected as a bioindicator for use in monitoring programmes linking changes in water quality to changes in the condition of coral reef ecosystems [45]. Reef rugosity correlates well with rocky reef fish community structure in Brazil [46], Hawaii [47], the Great Barrier Reef [48], Barbados [49], the Seychelles [50], and the Gulf of Mexico [51]. Rugose locations aid aggregation of Diadema antillarum urchins, important to keep macroalgae in check [52]. Interestingly, rugosity also correlates well with fish abundance on other reefs, for example with parrotfish (Scarid) abundance on reefs of Oahu, Hawaii [47], and rugosity has been used in regional modelling of coral habitats for marine conservation [53].

This study set out to quantify the size-structure of populations of a number of corals over time in order to test whether the Discovery Bay coral colonies were exhibiting resilience in the face of multiple acute stressors of hurricanes and bleaching, in addition to the recurring chronic stressors of overfishing and land development. In addition, the study tests whether reef rugosity might have influenced Jamaican reef resilience to, and subsequent recovery from, the 2005 bleaching event, and which might help inform management policy for reefs in the future.

\section{Methods}

Studies were conducted using SCUBA at five sites [Rio Bueno $\left(18^{\circ} 28.805^{\prime} \mathrm{N} ; 7^{\circ} 27.625^{\prime} \mathrm{W}\right)$, Dancing Ladies (18 $\left.28.369^{\prime} \mathrm{N} ; 7^{\circ} 24.802^{\prime} \mathrm{W}\right)$, M1 (18 $\left.28.337^{\prime} \mathrm{N} ; 7^{\circ} 24.525^{\prime} \mathrm{W}\right)$, Dairy Bull $\left(18^{\circ} 28.083^{\prime} \mathrm{N} ; 7^{\circ} 23.302^{\prime} \mathrm{W}\right)$, and Pear Tree Bottom (18 $\left.27.829^{\prime} \mathrm{N} ; 7^{\circ} 21.403^{\prime} \mathrm{W}\right)$ ] over a nine year period (2001-2009) along the fringing reefs surrounding Discovery Bay, Jamaica. GPS coordinates were determined using a hand-held GPS receiver (Garmin Ltd.). For all sites, four haphazardly located transects, each $15 \mathrm{~m}$ long and separated by at least $5 \mathrm{~m}$, were laid at between 
5-8.5 m depth, to minimise variation in growth rates due to depth. Biodiversity was measured for live species within $1 \mathrm{~m}$ either side of the transects. This work was conducted at Discovery Bay during July 15-31 in 2001, March 26-April 19 in 2002, March 18-April 10 in 2003, July 23-August 21 in 2004, July 18-August 13 in 2005, April 11-18 in 2006, December 30 in 2006-January 6 in 2007, July 30-August 16 in 2008, and July 27-August 8 in 2009. ANOVA was used to compare Shannon-Weiner Biodiversity Indices for Dairy Bull and M1 reef sites. The skewness coefficient (sk) [see 33] was used to quantify the relationship between the number of large and small corals within each population. The skewness for a normal distribution about the mean is zero, and any symmetric data should have a skewness near zero. Negative values for the skewness indicate data that are skewed left (more small colonies than in a normal distribution) and positive values for the skewness indicate data that are skewed right (more large colonies than in a normal distribution).

Rugosity $(R)$ was determined according to the formula:

$$
R=S r / S g
$$

where $S r=$ real surface distance between two points, and $S g=$ straight line geometric distance between two points. This was calculated over a $20 \mathrm{~m}$ distance, performed in triplicate, at each site, using photographic image analysis verified by the chain method [12]. Live corals were included.

\section{Results}

Figure $2 \mathrm{a}-\mathrm{c}$ shows the colony numbers of small and medium-sized colonies $\left(0-500 \mathrm{~mm}^{2}\right.$ surface area) of the corals Sidastrea siderea, Porites astreoides and Diploria strigosa, at the fringing reef sites Rio Bueno, M1, Dancing Ladies, Dairy Bull, and Pear Tree Bottom from 2001 to 2009. These dates covered the major bleaching event in 2005 and hurricane Ivan in 2004. All the sites showed some similarities in the trends for the three coral species shown here. However, there were differences between the different species studied at the sites. Skewness values (sk) were used to compare the colony size distribution from 2001-2009. For Siderastrea siderea, all sk values were positive (skewed to the left, with more large colonies than in a normal distribution), with little change between the dates (all sk values between 0.5 and 1.6). For Porites astreoides, all values were positive throughout, with an increase in skewness at Rio Bueno from 0.2 to 2.6, showing a marked change in distribution towards the larger colony sizes. At the other sites there were only small increases in sk values, with Pear tree Bottom showing a decrease in skewness from 0.9 to 0.6. Diploria strigosa colonies showed similar results to Porites astreoides, all sk values being positive, with an increase at Rio Bueno from 0.2 to 2.2 and at Pear Tree Bottom from 0.4 to 2.4; other sites showed similar sk values from 0.6 to 1.6.

There were significant relationships between mean rugosity value and the increase in smallest size classes for the corals Sidastrea siderea, Colpophyllia natans, Porites astreoides and Agaricia species for five sites on the fringing reefs near Discovery Bay [12]. There was also a significant linear relationship between percentage coral cover of Acropora cervicornis colonies with rugosity values for Dairy Bull reef, M1, New reef, Dancing Ladies, Rio Bueno and Pear Tree Bottom (Figure 3). The rugosity values themselves might well be driven by the effects of increasing abundance of Acropora branching corals. 
Figure 2. Graphs of annual changes in the colony numbers of small to medium-sized corals (0-500 mm² surface area) from 2001-2009 for (a), Sidastrea siderea; (b), Porites astreoides and (c), Diploria strigosa at Rio Bueno (RB), M1 (M1), Dancing Ladies (DL), Dairy Bull (DB), and Pear Tree Bottom (PTB).

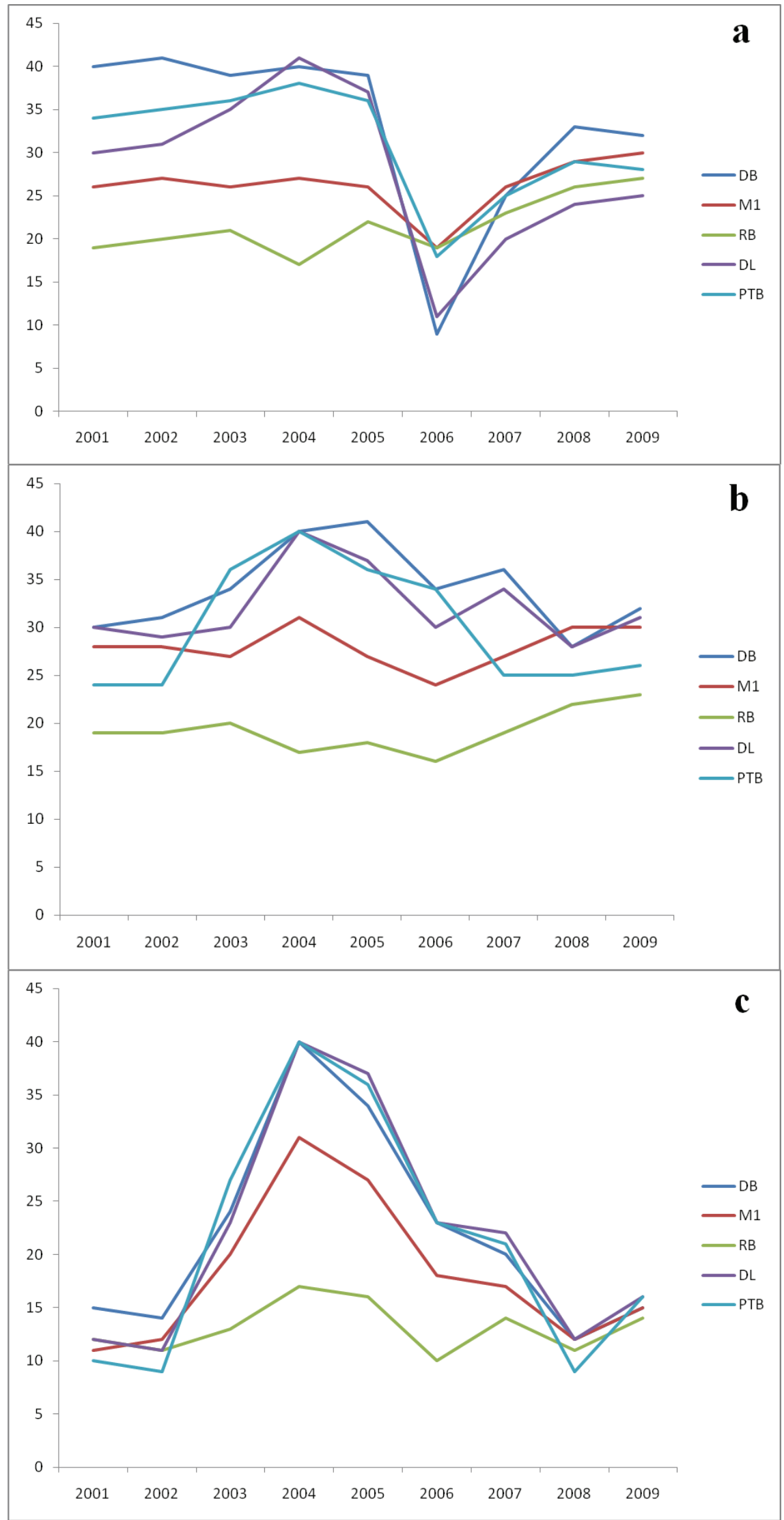


Figure 3. Percentage coral cover \pm 1 standard error of $A$. cervicornis colonies against rugosity values \pm 1 standard error, for Dairy Bull reef (2.3), M1 (1.17), New reef (1.7), Dancing Ladies (1.3), Rio Bueno (1.05) and Pear Tree Bottom (1.23). Mean rugosity values are in brackets. The line is a best-fit linear regression, with $\mathrm{R}^{2}=0.94$. Adapted from [12].

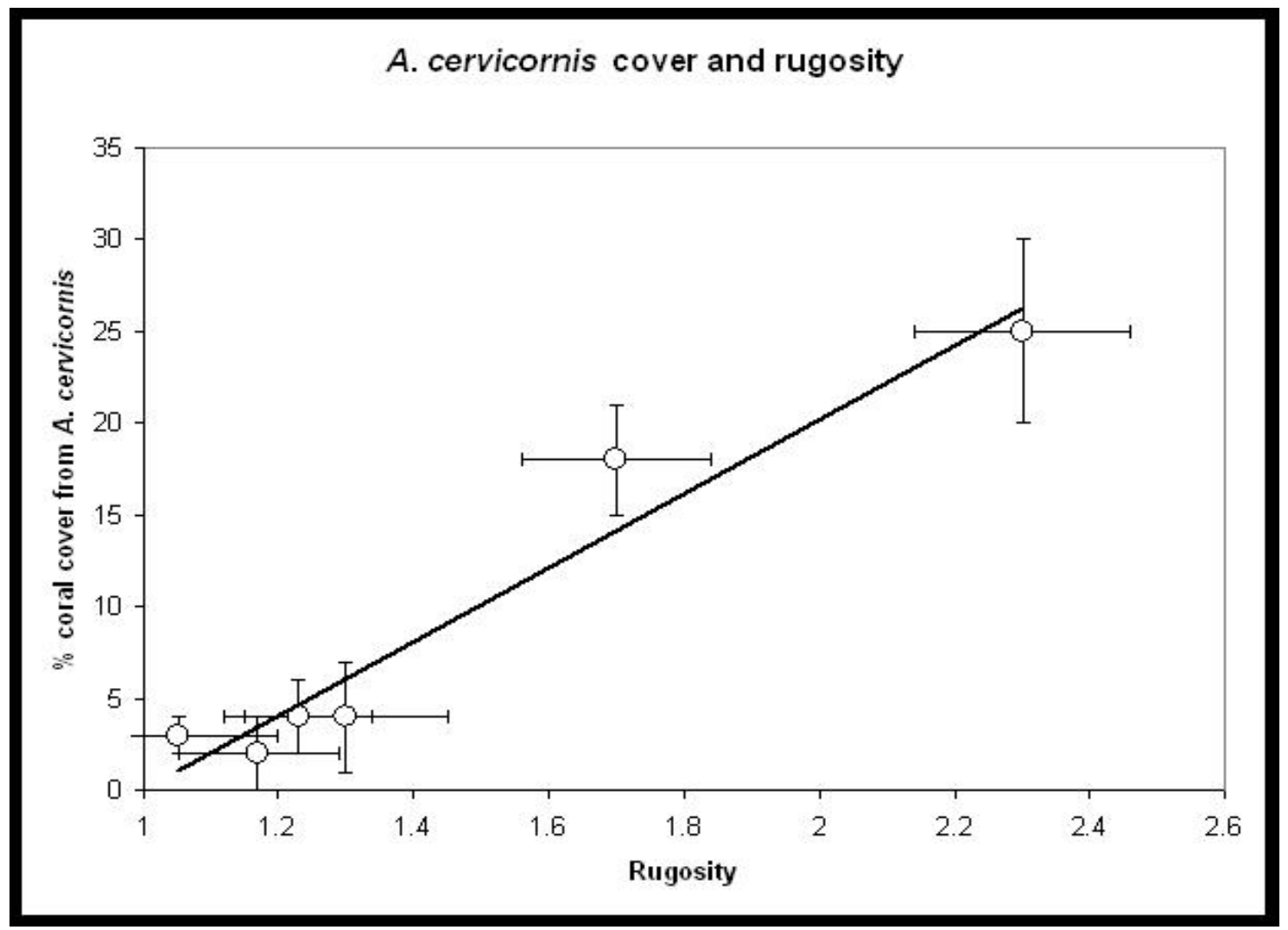

The two reefs with the highest rugosity values, Dairy Bull reef and New reef, exhibited the highest cover of the urchin Diadema antillarum and no macroalgal cover in the vicinity of A. cervicornis colonies. In contrast, the other reefs with lower rugosities exhibited extensive macroalgal cover and no Diadema antillarum. Dairy Bull reef was the site where studies resulted in the suggestion that there had been a rapid phase-shift reversal on Jamaican reefs [34], and which suffered a major loss of A. cervicornis in 2006 [32].

Table 1 shows mean percentage cover of live coral, macroalgae and live Acropora species along transects at Dairy Bull reef in 2005 (pre-bleaching), 2006, 2007 and 2008, the last three years post-bleaching. Cover of live coral, macroalgae and live Acropora for 2005 and 2006 are similar to figures reported by Quinn and Kojis [32]. While macroalgal cover remained essentially unchanged in 2007 and 2008, there were increases in live coral cover and live Acropora species in both 2007 and 2008. The majority of the increase in coral is represented by increases in live $A$. cervicornis. This is illustrated in Figure 4, which shows complete bleaching of an A. cervicornis colony typical of Dairy Bull reef after the mass bleaching event of 2005 and a large live colony of $A$. cervicornis typical of Dairy Bull reef in 2008. 
Table 1. Mean percentage cover of live coral, macroalgae and live Acropora species along transects at Dairy Bull, in 2005 (pre-bleaching), 2006, 2007 and 2008. Values are \pm standard errors. Adapted from [33].

\begin{tabular}{cccc}
\hline Year & Live coral (\%) & Macroalgae (\%) & Acropora species (\%) \\
\hline 2005 & $46 \pm 8$ & $8 \pm 3$ & $33 \pm 5$ \\
2006 & $13 \pm 5$ & $6 \pm 3$ & $2 \pm 2$ \\
2007 & $20 \pm 9$ & $6 \pm 3$ & $10 \pm 4$ \\
2008 & $31 \pm 7$ & $5 \pm 2$ & $22 \pm 7$ \\
\hline
\end{tabular}

Figure 4. Acropora cervicornis colonies at Dairy Bull reef. (a) Complete bleaching of A. cervicornis colony typical of Dairy Bull reef after the mass bleaching event of 2005 . Note partial bleaching of Sidastrea siderea colony in background. Photograph taken on the 14th April 2006; (b) Large live colony of A. cervicornis typical of Dairy Bull reef in 2008, showing excellent viability. Photograph taken on 11.08.2008. The vernier scale is $23 \mathrm{~cm}$ in length.

(a)

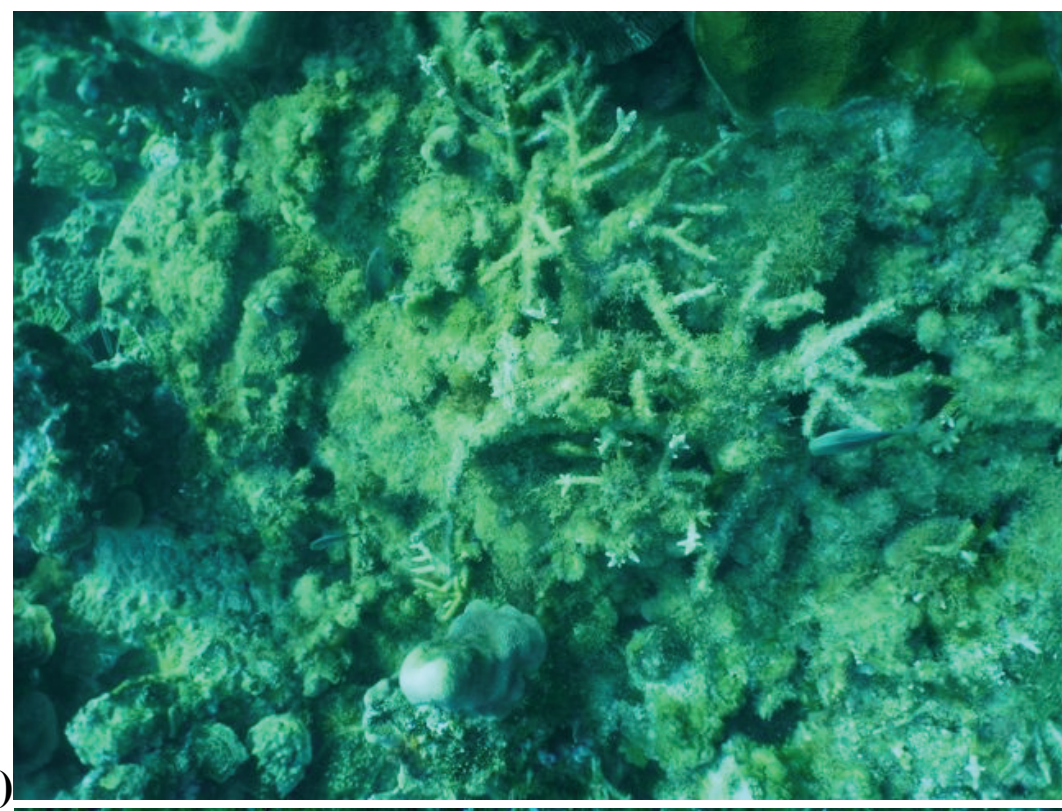

(b)

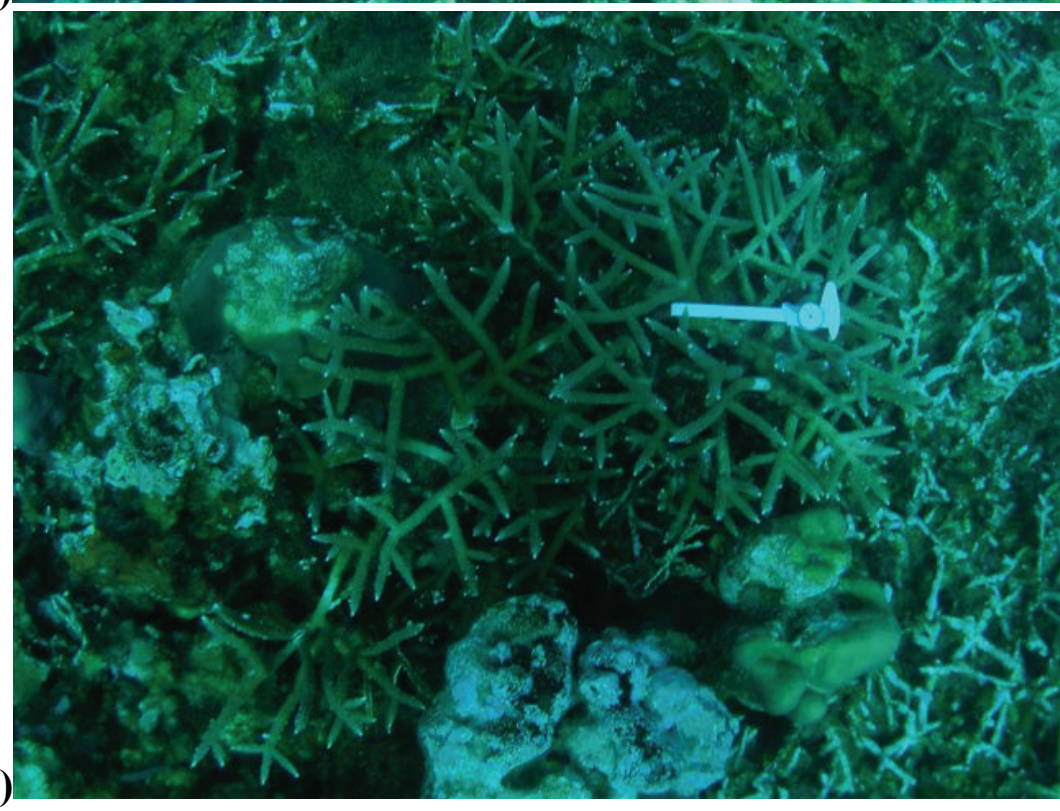


Figure 5 shows how Shannon-Wiener Biodiversity Index $(\mathrm{H})$ for two reef sites, M1, a reef site dominated by macroalgae, and Dairy Bull reef, in 2002 (pre-bleaching), 2006 (after the mass bleaching event in 2005) and in 2009 (post-bleaching). Differences at Dairy Bull reef, but not at M1, were significant at the 5\% level between 2002 and 2006, and between 2006 and 2009.

Figure 5. Shannon-Weiner Biodiversity Indices for Dairy Bull and M1 reef sites, in 2002, 2006 and 2009.

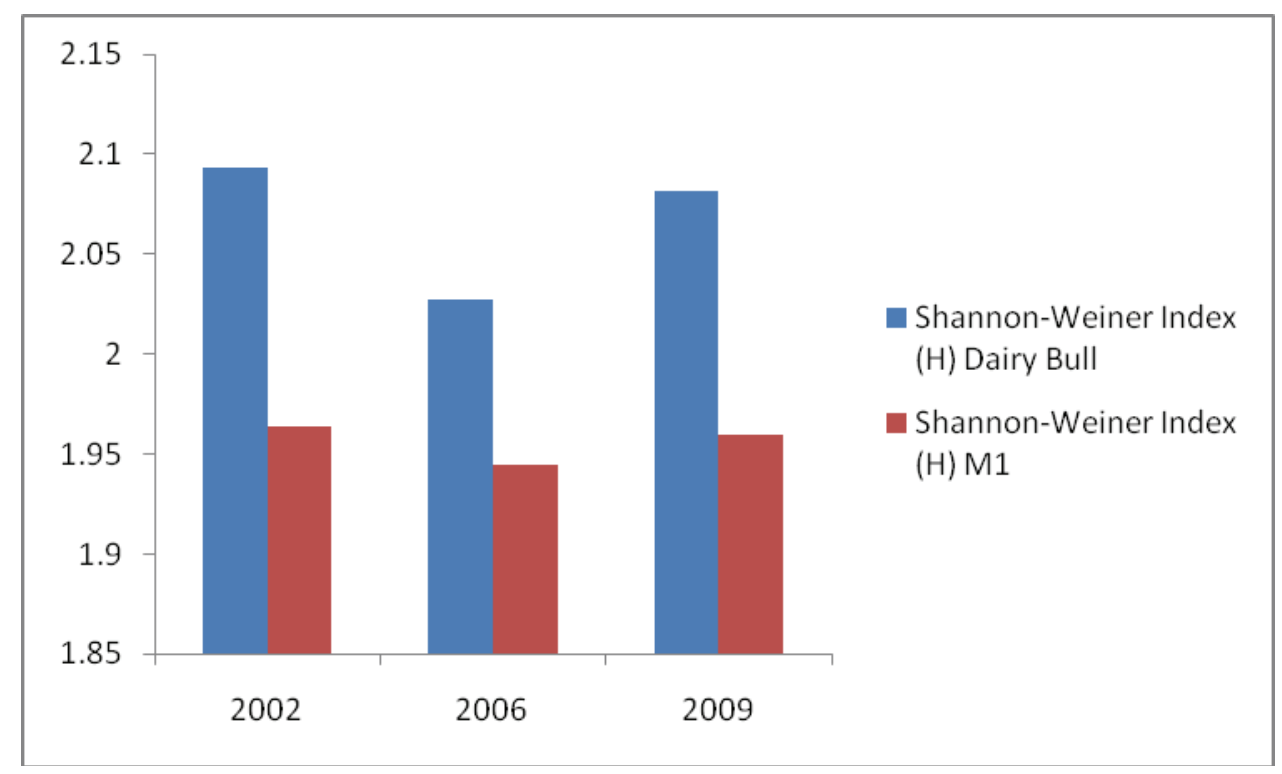

The biodiversity index for both reefs was lowered after the 2005 mass bleaching event, but had recovered at both sites in 2009. This pattern of biodiversity index change was also seen at the other reef sites studied.

Reefs are under stress from a variety of insults that act in synergy [54]. It may be that under conditions of low coral cover, low reef rugosity and low biodiversity, a major disturbance such as the 2005 bleaching event crosses a 'threshold' which then induces a cascade to induce the crossing of other thresholds, leading to a stable but less desirable alternative state [55]. An example where this has happened may be the reefs of Tobago, where coral recruitment declined significantly in years following hurricanes, tropical storms and coral bleaching events [40]. On the reefs of North Jamaica, there is a variable response and resilience, strongest in the case of Dairy Bull reef, which exhibits relatively high rugosity, coral cover and biodiversity with no significant macrogal cover [33]. Whether the niche diversification and multiple symbiont clades in corals at Dairy Bull Reef is sufficient to allow for adaptive radiation [56] in a period of intense climate change and ocean acidification is yet to be resolved.

Reef rugosity, contact of corals with macroalgae, and aggregation and competition between corals could influence reef integrity and resilience together with species and functional diversity, connectivity to larval sources, appropriate substrates for larval settlement, and protection from other anthropogenic effects $[41,42]$. As reefs become increasingly subjected to high sea surface temperatures and thermal stress [57], all these factors will have to be considered to development of reef management and conservation. 


\section{Discussion-Reef Management and Conservation}

Interestingly, when small and medium-sized coral colonies are considered over the period 2001-2009, while corals at most sites show similar trends (Figure 2a-c), only Sidastrea siderea colonies show similar trends to those where only small colonies $\left(0-250 \mathrm{~mm}^{2}\right.$ surface area) were considered [33]. In these cases there was a reduction in the colony numbers at all the sites in 2006, with subsequent increases for all species at all sites up to 2009 (see Figure 2a). However, for Porites astreoides and Diploria strigosa, the trends are more complex, with fewer medium-sized colonies recovering after the bleaching event of 2005 (Figure 2b-c). One reason might be the slower growth rates of these colonies, combined with run-off and pollution from resort development along the North coast during and after 2006 [see 33], to cater for the cricket World Cup. It is interesting that on the South coast of the island, fringing reefs around the cays near Kingston Harbour had estimated recruitment of non-branching corals that was consistent from 2002 to 2008 (MJC Crabbe, unpublished observations).

These findings stress the importance of good management for coral reefs in Jamaica. Integrated Coastal Zone Management (ICZM) is a complex worldwide governance issue requiring an integrated or coordinated approach. It involves many relevant stakeholders and policy initiatives need to be developed over long time scales. Ideally, marine ecosystems (i.e., corals and seagrass beds) should be closely linked to terrestrial ecosystems such as mangroves and coastal forests. In developing management policies, education and training to enhance human skills and institutional capacity in resource management is critical [58,59]. Such instruction has engaged many communities with inherent and long-standing challenges to sustainability and has been carried out within the context of Marine Protected Areas (MPAs) [60,61], indigenous community-based conservation [62,63], and disaster preparedness [64]. Partnerships can be important for ICZM, particularly where government policies link to local stakeholders (e.g., beach clean-up groups and marine wildlife associations) to produce collaborations that can involve people with vested interests in the coastal ecosystem (e.g., fishers, tour operators) and in ongoing management frameworks [65].

Estimates of the human benefits of coral reef ecosystems are interesting, and Figure 6 shows a compilation of economic values taken from several studies, and economic benefits can arise from many factors, from food and raw materials to climate regulation. However the most significant benefit is in tourism and recreation, and this is very important for many developing nations. For Jamaica, tourism is the second highest contributor to Gross Domestic Product (GDP), which in 2008 was estimated at around \$US 15 billion. In contrast, for Belize, where the fisheries industry plays a significant role in the economy, unlike in Jamaica, GDP was estimated at c. \$US 1.5 billion.

Marine reserves are an important tool in the sustainable management of many coral reefs [66-68]. One management approach that may help reef integrity is the development of a marine park or reserve that limits fishing, particularly of herbivorous fish. An example of a single marine reserve is the Great Barrier Reef in Australia operated and managed solely by the Great Barrier Reef Marine Park Authority (GBRMPA). In contrast, the second largest barrier reef in the world, the MesoAmerican Barrier Reef, has a number of single and separated marine reserves that exist along the barrier reef. Here, MPAs might find it of interest to share guidelines, practices and resources, underpinned by scientific research (see, e.g., [69]). Cooperative research and networking across all levels may help 
capacity building and encourages innovative approaches to management, particularly across coral reef, seagrass, mangrove and forest ecosystems [62,70-72].

Figure 6. Economic benefits from ecosystem services for coral reef ecosystems. Values are in US\$ / ha / year, on a logarithmic scale, and indicate the average value and the maximum value. Estimates taken from [77,78].

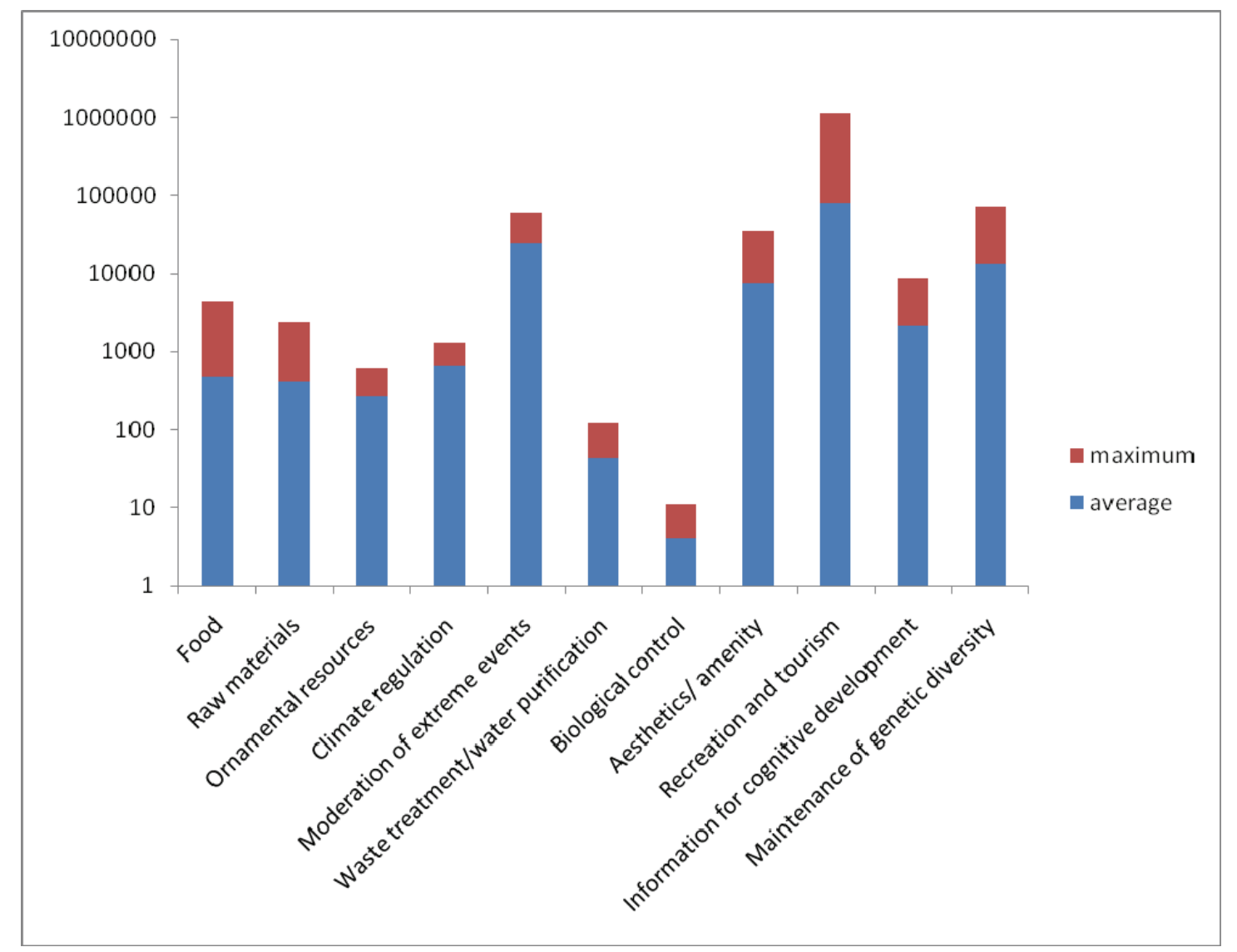

Many researchers (see, e.g., [73]) contend that the establishment of protected areas and policy development for sustainable conservation practices are key to sustainable ecosystems and preservation of reef integrity. Developing ICZM in the future will require both resources and iteration over many years to forge sustainable management processes and outcomes [74,75]. In some cases, there may be unresolvable differences among stakeholders. In these instances, it is important to have clear and disinterested leadership and a decision-making process that is widely respected to reduce the possibility that differences do not deteriorate into conflict. The different backgrounds and imperatives of stakeholders are important in management negotiations, particularly if the model used is outcome-driven rather than process-oriented [76].

Development of conservation and management of Jamaican reefs may find some aspects of a single country-wide MPA model advantageous:

1. The reefs around Jamaica could be designated as the Jamaican Coral Reef Marine Park. This could include all the fringing reefs, seagrass beds and mangroves from Negril to all along the north coast to the eastern tip of the island. On the south coast it could include Port Royal and Portland Bight. The advantage of this is that one can then consider protection of the Jamaican reefs as a whole. Another advantage is that climate change effects can be considered in a more holistic way. 
2. There could be a single body, possibly the National Environment Protection Agency (NEPA), or a subset of NEPA, given authority to manage the Park.

3. There could be a statement drawn up on 'protection and wise use' of the Park. Drawing up that statement should include all stakeholders, from fishermen through Industry and tourism to policy makers.

4. The Park could be managed using a 'zoning' system. This has been valuable in a number of areas, not least the Great Barier Reef. This will allow some areas to have greater restrictions (e.g. fishing, resort pollution, ship pollution) than others. Such zoning should help avoid the 'tragedy of the commons'. Zoning Plans define what activities can occur in which locations, both to protect the marine environment and to separate potentially conflicting activities.

5. Divisions into zones could be:

General Use

Conservation Park

Habitat Protection

Marine National Park

Another zone might be a Buffer Zone, next to a Marine National Park.

6. Each zone should have at least one of the following: (i) Community Partnerships, (ii) Local Marine Advisory Committees, (iii) Reef Advisory Committees. These bodies should be responsible for regulating their own area, and should be responsible to the overall Marine Park Management body. They would also be responsible for community involvement and information.

7. Permissions within the zones (e.g., for tourism, fishing etc.) would be given by the Jamaican Government, though NEPA.

This approach could link together the environment with tourism and business, so that environmental issues are seen as part of the way forward, not part of the problem. Even if smaller MPAs were developed around the island, the adoption of shared ownership of reef ecosystems is important as we move to a state of increased climate change.

\section{Acknowledgements}

I thank the Earthwatch Institute for funding, Anthony Downes, Peter Gayle, and the staff of the Discovery Bay Marine Laboratory for their invaluable help and assistance, to volunteers for their help underwater during this project, to the National Environmental Protection Agency in Jamaica for helpful conversations, and to the three anonymous reviewers for improvements to the manuscript. This is paper 738 from the Discovery Bay Marine Laboratory.

\section{References}

1. Gardner, T.A.; Côté, I.M.; Gill, J.A.; Grant, A.; Watkinson, A.R. Long-term region-wide declines in Caribbean corals. Science 2003, 301, 958-960.

2. Bellwood, D.R.; Hughes, T.P.; Folke, C.; Nyström, M. Confronting the coral reef crisis. Nature 2004, 429, 827-833.

3. Connell, J.H. Diversity in tropical rain forests and coral reefs. Science 1978, 199, 1302-1310. 
4. Rogers, C.S. Hurricanes and coral reefs: the intermediate disturbance hypothesis revisited. Coral Reef. 1993, 12, 127-137.

5. Stoll, P.; Prati, D. Intraspecific aggregation alters competitive interactions in experimental plant communities. Ecology 2001, 82, 319-327.

6. Hartley, S.; Shorrocks, B. A general framework for the aggregation model of coexistence. $J$. Anim. Ecol. 2002, 71, 651-662.

7. Karlson, R.H. Dynamics of Coral Communities; Kluwer Academic Publishers: Dordrecht, The Netherlands, 1999.

8. Karlson, R.H.; Cornell, H.V.; Hughes, T.P. Aggregation influences coral species richness at multiple spatial scales. Ecology 2007, 88, 170-177.

9. Lirman, D. Competition between macroalgae and corals: Effects of herbivore exclusion and increased algal biomass on coral survivorship and growth. Coral Reef. 2001, 19, 392-399.

10. Box, S.J.; Mumby, P.J. Effect of macroalgal competition on growth and survival of juvenile Caribbean corals. Mar. Ecol. Prog. Ser. 2007, 342, 139-149.

11. Idjadi, J.A.; Karlson, R.H. Spatial arrangement of competitors influences coexistence of reef-building corals. Ecology 2007, 88, 2449-2454.

12. Crabbe, M.J.C. Topography and spatial arrangement of reef-building corals on the fringing reefs of North Jamaica may influence their response to disturbance from bleaching. Mar. Environ. Res. 2010, 69, 158-162.

13. Hughes, T.P.; Tanner, J.E. Recruitment failure, life histories and long-term decline of Caribbean corals. Ecology 2000, 81, 2250-2263.

14. Coles, S.L.; Brown, E.K. Twenty-five years of change in coral coverage on a hurricane impacted reef in Hawai'i: the importance of recruitment. Coral Reef. 2007, 26, 705-717.

15. Mumby, P.J.; Hastings, A.; Edwards, H.J. Thresholds and the resilience of Caribbean coral reefs. Nature 2007, 450, 98-101.

16. Stat, M.; Morris, E.; Gates, R.D. Functional diversity in coral-dinoflagellate symbiosis. Proc. Natl. Acad. Sci. USA 2008, 105, 9256-9261.

17. Mora, C. A clear human footprint in the coral reefs of the Caribbean. Proc. R. Soc. Lond. B Biol. Sci. 2008, 275, 767-773.

18. Soong, K. Colony size as species character in massive reef corals. Coral Reef. 1993, 12, 77-83.

19. Meesters, E.H.I.; Hilterman, M.; Kardinaal, E.; Keetman, M.; de Vries, M.; Bak, R.P.M. Colony size-frequency distributions of scleractinian coral populations: spatial and interspecific variation. Mar. Ecol. Prog. Ser. 2001, 209, 43-54.

20. Smith, L.D.; Devlin, M.; Haynes, D.; Gilmour, J.P. A demographic approach to monitoring the health of coral reefs. Mar. Pollut. Bull. 2005, 51, 399-407.

21. Woodley, J.D.; Chornesky, E.A.; Clifford, P.A.; Jackson, J.B.C.; Kaufman, L.S.; Knowlton, N.; Lang, J.C.; Pearson, M.P.; Porter, J.W.; Rooney, M.C.; Rylaarsdam, K.W.; Tunnicliffe, V.J.; Wahle, C.M.; Wulff, J.L.; Curtis, A.S.G.; Dallmeyer, M.D.; Jupp, B.P.; Koehl, M.A.R.; Neigel, J.; Sides, E.M. Hurricane Allen's impact on Jamaican coral reefs. Science 1981, 214, 749-755.

22. Crabbe, M.J.C.; Mendes, J.M.; Warner, G.F. Lack of recruitment of non-branching corals in Discovery Bay is linked to severe storms. Bull. Mar. Sci. 2002, 70, 939-945.

23. Jackson, J.B.C. Reefs since Columbus. Proc. 8th. Int. Coral Reef Symp. 1997, 1, 97-106. 
24. Hawkins, J.P.; Roberts, C.M. Effects of artisanal fishing on Caribbean coral reefs. Conserv. Biol. 2004, 18, 215-226.

25. Hughes, T.P. Catastrophes, phase shifts and large-scale degradation of a Caribbean coral reef. Science 1994, 265, 1547-1551.

26. Aronson, R.B.; Precht, W.F. Evolutionary paleoecology of Caribbean coral reefs. In Evolutionary Paleoecology: The Ecological Context of Macroevolutionary Change; Allmon, W.D., Bottjer, D.J., Eds.; Columbia University Press: New York, NY, USA, 2001; pp. 171-233.

27. Greenaway, A.M.; Gordon-Smith, D.-A. The effects of rainfall on the distribution of inorganic nitrogen and phosphorus in Discovery Bay, Jamaica. Limnol. Oceanogr. 2006, 51, 2206-2220.

28. Bruno, J.F.; Sweatman, H.; Precht, W.F.; Selig, E.R.; Schutte, V.G.W. Assessing evidence of phase shifts from coral to macroalgal dominance on coral reefs. Ecology 2009, 90, 1478-1484.

29. Liu, P.-J.; Shao, K.-T.; Jan, R.-Q.; Fan, T.-Y.; Wong, S.-L.; Hwang, J.-S.; Chen, J.-P.; Chen, C.-C.; Lin, H.-J. A trophic model of fringing coral reefs in Nanwan Bay, southern Taiwan suggest overfishing. Mar. Environ. Res. 2009, 68, 106-117.

30. Jones, L.; Alcolado, P.M.; Cala, Y.; Cobián, D.; Coelho, V.; Hernández, A.; Jones, R.; Mallela, J.; Manfrino, C. The effects of coral bleaching in the northern Caribbean and western Atlantic. In Status of Caribbean Coral Reefs after Bleaching and Hurricanes in 2005; Wilkinson, C., Souter, D., Eds.; Global Coral Reef Monitoring Network, and Reef and Rainforest Research Centre: Townsville, Australia, 2008; pp. 73-83.

31. Wilkinson, C.; Souter, D. Status of Caribbean Coral Reefs after Bleaching and Hurricanes in 2005; Global Coral Reef Monitoring Network, and Reef and Rainforest Research Centre: Townsville, Australia, 2008.

32. Quinn, N.J.; Kojis, B.L. The recent collapse of a rapid phase-shift reversal on a Jamaican north coast reef after the 2005 bleaching event. Int. J. Trop. Biol. 2008, 56, 149-159.

33. Crabbe, M.J.C. Scleractinian coral population size structures and growth rates indicate coral resilience on the fringing reefs of North Jamaica. Mar. Environ. Res. 2009, 67, 189-198.

34. Idjadi, J.A.; Lee, S.C.; Bruno, J.F.; Precht, W.F.; Allen-Requa, L.; Edmunds, P.J. Rapid phase-shift reversal on a Jamaican coral reef. Coral Reef. 2006, 25, 209-211.

35. Meesters, E.H.I.; Hilterman, M.; Kardinaal, E.; Keetman, M.; de Vries, M.; Bak, R.P.M. Colony size-frequency distributions of scleractinian coral populations: spatial and interspecific variation. Mar. Ecol. Prog. Ser. 2001, 209, 43-54.

36. Loya, Y. Skeletal regeneration in a Red Sea scleractinian coral population. Nature 1976, 261, 490-491.

37. Abrego, D.; Ulstrup, K.E.; Willis, B.L.; van Oppen, M.J.H. Species-specific interactions between algal endosymbionts and coral hosts define their bleaching response to heat and light stress. Proc. R. Soc. Lond. B Biol. Sci. 2008, 275, 2273-2282.

38. Donner, S.D.; Knutson, T.R.; Oppenheimer, M. Model-based assessment of the role of human-induced climate change in the 2005 Caribbean coral bleaching event. Proc. Natl. Acad. Sci. USA 2007, 104, 5483-5488. 
39. Morgan, J.; Heron, S.; Eakin, M. The 2005 bleaching event: coral-list log. In Status of Caribbean Coral Reefs after Bleaching and Hurricanes in 2005; Wilkinson, C., Souter, D., Eds.; Global Coral Reef Monitoring Network, and Reef and Rainforest Research Centre, Townsville, Australia, 2008; pp. 37-44.

40. Mallela, J.; Crabbe, M.J.C. Hurricanes and coral bleaching linked to changes in coral recruitment in Tobago. Mar. Environ. Res. 2009, 68, 158-162.

41. Nyström, M.; Graham, N.A.J.; Lokrantz, J.; Norström, A.V. Capturing the cornerstones of coral reef resilience: linking theory to practice. Coral Reef. 2008, 27, 795-809.

42. Halford, A.R.; Caley, M.J. Towards an understanding of resilience in isolated coral reefs. Glob. Change Biol. 2009, 15, 3031-3045.

43. Alvarez-Filip, L.; Dulvy, N.K.; Gill, J.A.; Côté, I.M.; Watkinson, A.R. Flattening of Caribbean coral reefs: region-wide declines in architectural complexity. Proc. R. Soc. Lond. B Biol. Sci. 2009, 276, 3019-3025.

44. Adjeroud, M.; Michonneau, F.; Edmunds, P.J.; Chancerelle, Y.; de Loma, T.L.; Penin, L.; Thibaut, L.; Vidal-Dupiol, J.; Salvat, B.; Galzin, R. Recurrent disturbances, recovery trajectories, and resilience of coral assemblages on a South Central Pacific reef. Coral Reef. 2009, 28, 775-780.

45. Cooper, T.F.; Gilmour, J.P.; Fabricius, K.E. Bioindicators of changes in water quality on coral reefs: review and recommendations for monitoring programmes. Coral Reef. 2009, 28, 589-606.

46. Chaves, L.D.T.; Monteiro-Neto, C. Comparative analysis of rocky reef fish community structure in coastal islands of south-eastern Brazil. J. Mar. Biol. Assoc. UK 2009, 89, 609-619.

47. Howard, K.G.; Schumacher, B.D.; Parrish, J.D. Community structure and habitat associations of parrotfishes on Oahu, Hawaii. Environ. Biol. Fish. 2009, 85, 175-186.

48. Emslie, M.J.; Cheal, A.J.; Sweatman, H.; Delean, S. Recovery from disturbance of coral and reef fish communities on the Great Barrier Reef, Australia. Mar. Ecol. Prog. Ser. 2008, 371, 177-190.

49. Chapman, M.R.; Kramer, D.L. Gradients in coral reef fish density and size across the Barbados Marine reserve boundary: effects of reserve protection and habitat characteristics. Mar. Ecol. Prog. Ser. 1999, 181, 81-96.

50. Wilson, S.K.; Graham, N.A.J.; Polunin, N.V.C. Appraisal of visual assessments of habitat complexity and benthic composition on coral reefs. Mar. Biol. 2007, 151, 1069-1076.

51. Rooker, J.R.; Dokken, Q.R.; Pattengill, C.V.; Holt, G.J. Fish assemblages on artificial and natural reefs in the Flower Garden Banks National Marine Sanctuary, USA. Coral Reef. 1997, 16, 83-92.

52. Macia, S.; Robinson, M.P.; Nalevanko, A. Experimental dispersal of recovering Diadema antillarum increases grazing intensity and reduces macroalgal abundance on a coral reef. Mar. Ecol. Prog. Ser. 2007, 348, 173-182.

53. Dunn, D.C.; Halpin, P.N. Rugosity-based regional modelling of hard bottom habitat. Mar. Ecol. Prog. Ser. 2009, 377, 1-11.

54. Anthony, K.R.N.; Kline, D.I.; Diaz-Pulido, G.; Dove, S.; Hoegh-Guldberg, O. Ocean acidification causes bleaching and productivity loss in coral reef builders. Proc. Natl. Acad. Sci. USA 2008, 105, 17442-17446. 
55. Kinzig, A.P.; Pacala, S.W. Successional biodiversity and ecosystem functioning. In The Functional Consequences of Biodiversity; Kinzig, A.P., Pacala, S.W., Tilman, D., Eds.; Princeton University Press: Princeton, NJ, USA, 2001; pp. 175-212.

56. Brockhurst, M.A.; Colegrave, N.; Hodgson, D.J.; Buckling, A. Niche occupation limits adaptive radiation in experimental microcosms. PLoS One 2007, 2, e193.

57. Thompson, D.M.; van Woesik, R. Corals escape bleaching in regions that recently and historically experienced frequent thermal stress. Proc. R. Soc. Lond. B Biol. Sci. 2009, 276, 2931-2940.

58. Wescott, G. Partnerships for capacity building: community, governments and universities working together. Ocean Coast. Manage. 2002, 45, 549-571.

59. Balgos, M. Integrated coastal management and marine protected areas in the Philippines: concurrent developments. Ocean Coast. Manage. 2005, 48, 972-995.

60. Chircop, A. Introduction to capacity building. Ocean Coast. Manage. 1998, 38, 67-68.

61. Crabbe, M.J.C.; Martinez, E.; Garcia, C.; Chub, J.; Castro, L.; Guy, J. Is capacity building important in policy development for sustainability? A case study using action plans for sustainable Marine Protected Areas in Belize. Soc. Nat. Resource. 2010, 23, 181-190.

62. Mutandwa, E.; Gadzirayi, C. Impact of community-based approaches to wildlife management: a case study of the CAMPFIRE programme in Zimbabwe. Int. J. Sustain. Dev. World Ecol. 2007, 14, 336-344.

63 Tai, H.S. Development through conservation: an institutional analysis of indigenous community-based conservation in Taiwan. World Develop. 2007, 35, 1186-1203.

64. Allen, K. Community-based disaster preparedness and climate adaptation: local capacity-building in the Philippines. Disasteres 2006, 30, 81-101.

65. Stojanovic, T.; Barker, N. Improving governance through local coastal partnerships in the UK. Geog. J. 2008, 174, 344-360.

66. Williams, I.; Polunin, N. Differences between protected and unprotected reefs of the Western Caribbean in attributes preferred by dive tourists. Environ. Cons. 2000, 27, 382-391.

67. Cho, L. Marine protected areas: a tool for integrated coastal management in Belize. Ocean Coast. Manage. 2005, 48, 932-947.

68. Mumby, P.J; Harborne, A.R. Marine reserves enhance the recovery of corals on Caribbean reefs. PLoS One 2010, 5, e8657.

69. Hills, J.; Alcock, D.; Higham, T.; Kirkman, H.; LeTissier, M.; Pagdilao, C.; Samonte, P.; Smith, T. Capacity building for Intergrated Coastal management in Asia-Pacific: the case for case studies. Coast. Manage. 2006, 34, 323-337.

70. Christie, P.; White, A. Best practices for improved governance of coral reef marine protected areas. Coral Reef. 2007, 26, 1047-1056.

71. Johnson, T.; van Densen, W. Benefits and organisation of cooperative research for fisheries management. ICES J. Mar. Sci. 2007, 64, 834-840.

72. Poulsen, S. Examples of capacity building cooperation. Waste Manage. Res. 2007, 25, 283-287.

73. Mumby, P.; Steneck, R. Coral reef management and conservation in light of rapidly evolving ecological paradigms. Trends Ecol. Evol. 2008, 23, 555-563.

74. Coffin, B. Building ethical capacity for collaborative research. Nonprofit Volunt. Sect. Q. 2005, 34, 531-539. 
75. Mow, J.; Taylor, E.; Howard, M.; Baine, M.; Connolly, E.; Chiquillo, M. Collaborative planning and management of the San Andres Archipelago's coastal and marine resources: a short communication on the evolution of the Seaflower Marine Protected Area. Ocean Coast. Manage. 2007, 50, 209-222.

76. Norris-Raynbird, C. Mediation-fostered equality?-An examination of environmental negotiations from a power/process perspective. Proc. Gulf Carib. Fish. Inst. 2004, 55, 155-177.

77. TEEB - The Economics of Ecosystems and Biodiversity for national and international policymakers-Summary: Responding to the value of nature. 2009; p. 47. Available online: http://www.unep.org/Documents.Multilingual/Default.asp?DocumentID=602\&ArticleID=6371\&l $=\mathrm{en} \& \mathrm{t}=$ long (accessed on 1 March 2010).

78. Burke, L.; Selig, E.; Spalding, M. Reefs at Risk in Southeast Asia; World Resources Institute (WRI): Washington, DC, USA. Available online: http://www.wri.org (accessed on 8 March 2010).

(C) 2010 by the authors; licensee MDPI, Basel, Switzerland. This article is an Open Access article distributed under the terms and conditions of the Creative Commons Attribution license (http://creativecommons.org/licenses/by/3.0/). 